\title{
Homoseksualizm w starożytnej Mezopotamii. Przegląd źródeł
}

\author{
Homosexuality in Ancient Mesopotamia. A Survey of Sources
}

\section{MACIEJ MÜNNICH}

Katolicki Uniwersytet Lubelski Jana Pawła II

munnich@kul.pl, ORCID: 0000-0003-0063-2799

\begin{abstract}
Streszczenie: Homoseksualizm był znanym, choć rzadkim zjawiskiem w społeczeństwach starożytnej Mezopotamii. Jednocześnie różnił się on od współczesnego, był to bowiem wyraz dominacji jednego mężczyzny oraz pohańbienia drugiego. Jeśli miał miejsce w odniesieniu do osoby równej, wówczas był karalny, jednak na przykład wrogowi można było życzyć, by stał się męską prostytutką. Inną formą homoseksualizmu była prostytucja sakralna w ramach kultu Inanny/Isztar. Jednak i w tym wypadku personel świątynny, zaangażowany (jako partner pasywny) w taką formę kultu, miał status niższy aniżeli wolni mężczyźni. Brak jakichkolwiek wzmianek o zachowaniach homoseksualnych wśród kobiet.
\end{abstract}

Słowa kluczowe: homoseksualizm, prostytucja, nierząd sakralny, Mezopotamia

Abstract: Homosexuality was a known, though rare, phenomenon in ancient Mesopotamia. Ancient expressions of homosexuality differed significantly from modern ones, because in antiquity it usually meant the domination of one man and the disgrace of the other. For this reason, an enemy could be wished to become a male prostitute. If homosexual acts took place between persons of equal status, then it was punishable. Another form of homosexuality was sacred prostitution as part of the cult of Inanna/Ishtar. The male temple personnel involved (as passive partners) in such a form of worship possessed a social status lower than that of free men. There are no known records or depictions of homosexual behavior among women.

Keywords: homosexuality, prostitution, religious harlotry, Mesopotamia

Najbardziej znanym spośród źródeł starożytnego Bliskiego Wschodu odnoszących się do homoseksualizmu jest w naszym kręgu kulturowym Biblia. Wystarczy wspomnieć o przepisach prawnych zawartych w Księdze Kapłańskiej: „Nie będziesz obcował z mężczyzną, tak jak się obcuje z kobietą. To jest obrzydliwość!” $(18,22)$ oraz „Ktokolwiek obcuje cieleśnie z mężczyzną, tak jak się obcuje z kobietą, popełnia obrzydliwość. Obaj będą ukarani śmiercią, ich krew [spadnie] na nich" $(20,13)^{1}$.

Inny fragment zdecydowanie negatywnie odnoszący się do homoseksualizmu to opis wizyty aniołów w Sodomie. Zostali oni opisani jako mężczyźni ('ănāšî̀m). Mieszkańcy występnego miasta chcą „poznać” gości Lota. Charakter owego „poznania”

1 Cytaty biblijne za Biblia Tysiąclecia, wyd. 5 (Warszawa: Pallottinum 2006) (=BT). 
$\left(y d^{\circ}\right)$ jest oczywisty², a Lot - chcąc zachować święte prawo gościnności - proponuje nawet, że da mieszkańcom swoje dziewicze córki, byleby oszczędzono gości. Nie trzeba dodawać, że zachowanie mieszkańców Sodomy zostało ukarane.

Z pewnością szczegółowe rozważania o biblijnych tekstach odnoszących się do homoseksualizmu czytelnik znajdzie w innych artykułach tego tomu. $Z$ tego względu źródła biblijne nie będą tutaj omawiane. Można jednak zadać pytanie: Na ile starotestamentowe podejście do homoseksualizmu jest typowe w świecie starożytnego Bliskiego Wschodu? Jakie wnioski można wyciągnąć, stykając się z innymi źródłami? Niniejszy artykuł ma za zadanie przedstawić źródła bliskowschodnie, pochodzące z terenów Mezopotamii i poruszające temat homoseksualizmu. Zbiór źródeł (wraz z wymienionymi ważniejszymi edycjami i tłumaczeniami) $\mathrm{i}$ ich analiza mają w zamierzeniu stanowić materiał ułatwiający osadzenie tekstu biblijnego w szerszym kontekście.

\section{Prawa asyryjskie}

Wobec istnienia biblijnych norm prawnych dotyczących zachowań homoseksualnych, najbardziej oczywiste wydaje się zwrócenie uwagi na mezopotamskie zbiory praw, które jakże często są przywoływane w różnych porównaniach z tekstem Starego Testamentu. Należy jednak już na początku zaznaczyć, że problematyka homoseksualizmu pojawia się w tych źródłach wyjątkowo rzadko. Najstarsze zbiory (np. tzw. kodeks Urnammu, kodeks Lipitisztara, kodeks z Esznunny, kodeks Hammurabiego) w ogóle nie wspominają o takim zagadnieniu. Jednocześnie problem zdrady małżeńskiej występuje w nich dość często. Brak przepisów prawnych odnoszących się do homoseksualizmu można zrzucić na karb uszkodzeń tekstu pierwszych trzech zbiorów (choć oczywiście argumentum ex silentio jest zawsze dość wątpliwe metodologicznie). Jednak kodeks Hammurabiego zachował się praktycznie w całości i nie ulega wątpliwości, że po prostu nie zawiera regulacji prawnych dotyczących tego rodzaju zachowań. Po raz pierwszy zagadnienie homoseksualizmu pojawia się dopiero w zbiorze praw średnioasyryjskich, pochodzącym z XIV w. przed Chr. (zachowana kopia z XI w.):

[A19:] Jeśli człowiek ukradkiem rozpuszcza pogłoski o swym towarzyszu mówiąc: „Każdy go scudzołożył”, albo podczas kłótni wobec (innych) ludzi mówi: „Każdy cię scudzołożył. Wniosę oskarżenie przeciwko tobie", ale nie może oskarżenia udowodnić, (wówczas) po-

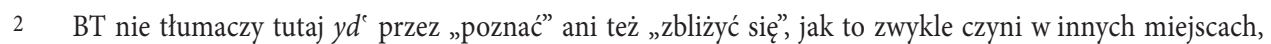
gdzie wyraz ten ma ewidentnie seksualne znaczenie, lecz daje „obcować”, a w czwartym wydaniu było "poswawolić". 
winni tego człowieka uderzyć 50 razy kijem. (Człowiek ten) powinien przez miesiąc odbywać służbę dla króla; powinni ostrzyc go i powinien zapłacić 3600 szekli cyny.

[A20:] Jeśli człowiek scudzołoży swego towarzysza i wniosą oskarżenie przeciwko niemu i uznają za winnego, (wówczas) powinni go scudzołożyć i zrobią z niego eunucha³.

Powyższe przepisy wymagają krótkiego komentarza. Kluczowy termin „scudzołożyć” to w oryginale czasownik nâku, który oznacza „nielegalnie współżyć, cudzołożyć" ". Występuje on zarówno w koniugacji czynnej, jak i zwrotnej, a w odniesieniu do kobiet w biernej. Dlatego też w tłumaczeniu zdecydowano się na archaizm „scudzołożyć" występujący w dawnej polszczyźnie, choć obecnie już nieużywany. We współczesnym języku polskim dobrym odpowiednikiem, biorąc pod uwagę możliwą łatwą zmianę stron gramatycznych, byłby czasownik wywodzący się od popularnej przyprawy, jednak wydaje się, że taki przekład byłby nazbyt pikantny i z uwagi na charakter prezentowanych rozważań - niewłaściwy. Natomiast tłumaczenie „cudzołożyć”, „dopuścić się cudzołóstwa” nie w pełni odpowiada w tym kontekście znaczeniu czasownika akadyjskiego. Takie tłumaczenie zakłada bowiem zgodne działanie obu stron i w języku polskim wprowadza negatywną ocenę moralną obu osób współżyjących płciowo ${ }^{5}$. Jednak w przypadku A20 oznaczałoby to karanie tylko jednego z „cudzołożników”, a co gorsza, dopuścić się cudzołóstwa mieliby także sami sędziowie. Na dodatek w tym drugim przypadku mowa jest z pewnością o akcie seksualnym przeprowadzonym wbrew woli skazanego. W takim kontekście „scudzołożyć” lepiej odpowiada oryginałowi, ponieważ może sugerować użycie przemocy, gwałt. Warto zaznaczyć, że czasownik nâku - użyty tutaj w odniesieniu do kontaktów homoseksualnych - w zdecydowanej większości źródeł odnosi się do kontaktów heteroseksualnych ${ }^{7}$. Jest to oczywiste wobec absolutnej dominacji wzmianek o relacjach seksualnych pomiędzy mężczyzną a kobietą w stosunku do źródeł wspominających o kontaktach homoseksualnych.

W pierwszym z podanych przepisów prawnych pojawia się także czasownik gadāmu, „obciąć”, „ostrzyc”. Wbrew dawniej przyjmowanym propozycjom, nie jest tu

3 Zob. Roth, Law Collections, 160; por. ANET 181; Lipiński, Prawo bliskowschodnie, 179.

4 CAD N1, 197-198. Czasownik ten nie wskazuje po prostu na samo współżycie seksualne, lecz raczej na jego formę ocenianą jako niedozwoloną. Dla „zwykłego” współżycia język akadyjski stosował wiele czasowników, przede wszystkim rehu („współżyć”, „płodzić”), ale też edû („poznać”), ekēpu („zbliżyć się”), lapātu („dotknąc’”), nakāpu/naqābu („penetrować”), qerēbu („zbliżyć się"), sinnišūtu („,mieć sprawę kobiecą"), șalālu („leżeć”), țeĥ̀ („zbliżyć się").

5 Wyrazy „cudzołożyć”, „cudzołożnik” są bez wątpienia nacechowane negatywnie.

6 Wbrew praktyce prawa (por. A13), gdzie mowa jest o karze śmierci dla obojga cudzołożących - mężczyzny i kobiety.

7 Czasownik ten, dość szeroko używany, z pewnością nie ma znaczenia „uprawiać seks jako dominujący [tj. penetrujący] partner" (tak: Gagnon, The Bible and Homosexual Practice, 6-7), co sugerowałoby przede wszystkim kontakty homoseksualne. 
mowa o kastracji ${ }^{8}$, ponieważ czasownik ten odnosi się wyłącznie do włosów9. Zresztą byłoby czymś zadziwiającym, że kara za pomówienie byłaby surowsza (chłosta, roboty przymusowe, kastracja, grzywna), aniżeli za sam gwałt homoseksualny (gwałt i kastracja). Zresztą ta sama kara występuje także w poprzedzającym ten przepis paragrafie A18, gdzie jest przewidziana za fałszywe oskarżenie cudzej żony o niewierność. Jedyną różnicą w sankcjach jest zwiększenie o dziesięć liczby uderzeń w przypadku oskarżenia mężczyzny. Z pewnością zatem kastracja mężczyzny nie mogła być wyznaczona za przewinienie polegające na rzuceniu fałszywego oskarżenia.

Rzeczywista kastracja jest natomiast przewidziana w paragrafie A20, gdzie ma dotknąć gwałciciela innego mężczyzny. Użyty termin ša rēši, w tym kontekście „eunuch”, ma szersze znaczenie, ponieważ - szczególnie we wcześniejszych tekstach - oznacza ogólnie żołnierza, oficera, urzędnika ${ }^{10}$. Dopiero w niektórych tekstach średnioasyryjskich i późniejszych pojawia się znaczenie „eunuch”, choć nie wypiera nigdy zupełnie podstawowego sensu. Najprawdopodobniej wynika to z tego, że w haremach władców część strażników musiała być eunuchami, dla zapewnienia absolutnej pewności nieskalania żon królewskich.

Warto przy tym zauważyć, że w omawianym zbiorze praw karą za świadomy gwałt na mężatce jest kara śmierci dla mężczyzny (A12). Zatem gwałt homoseksualny jest traktowany łagodniej aniżeli heteroseksualny. W przepisach nie podano przesłanek takiego stanu rzeczy. Można jedynie domniemywać, że gwałt na mężatce jest nie tylko aktem zamachu na własność innego mężczyzny (tak wszak jest traktowana żona we wszystkich prawach starożytnego Bliskiego Wschodu, łącznie z Dekalogiem), ale może także przynieść trwałe skutki, obniżające wartość tej własności, czyli ciążę z obcym mężczyzną. W takiej sytuacji - w oczach mieszkańców Asyrii - strata właściciela jest znaczna. Natomiast w przypadku gwałtu homoseksualnego zagrożenie takie nie występuje. Podstawową stratą jest w tym wypadku uchybienie godności mężczyzny. W stosunku do mężczyzn o równych prawach - co wyraźnie zaznacza tekst, określając sprawcę jako „człowieka wolnego, obywatela” a’ìlu, zaś drugiego jako jego "towarzysza, sąsiada” tapp $\hat{u}$ - takie zachowanie dowodzi upokorzenia jednego z nich. Dlatego też posądzenie zawarte w A18, że mężczyzna został „scudzołożony”, traktowane jest jako pohańbienie i - jeśli nie jest prawdziwe - godne jest kary. Dodatkowo gwałciciel upokarzający innego mężczyznę ma zostać według paragrafu A19 najpierw pohańbiony w ten sam sposób, a dopiero potem wykastrowany, co z jednej strony zapewnia, że już swego niecnego czynu nie powtórzy, z drugiej zaś - sprowadza go do rzędu kobiet, czyli osób mających mniejsze prawa niż mężczyźni. Możemy jedynie domyślać się, że w odniesieniu do nierównorzędnych członków społeczeń-

Tak tłumaczył Theophile J. Meek w ANET 181, a za nim przyjął m.in. David F. Greenberg (The Construction of Homosexuality, 125, przyp. 4).

9 CAD G, 8.

10 CAD R, 292-296. 
stwa, czyli człowieka wolnego i niewolnika, taki problem prawny dla prawa asyryjskiego nie istniał. Pan mógł wszak ze swym niewolnikiem zrobić, co mu się podobało, w tym także zgwałcić, podobnie jak to miało miejsce w odniesieniu do niewolnic. Nie ulega zatem wątpliwości, że prawo asyryjskie, podobnie jak inne zbiory praw, nie wypowiada się na temat samego aktu homoseksualnego (np. z niewolnikiem czy jeńcem). Natomiast współżycie między równoprawnymi członkami społeczeństwa traktuje jako formę upokorzenia osoby biernej i jednocześnie jako formę dominacji przez osobę dokonującą penetracji.

\section{Złorzeczenia królewskie}

Podobne podejście widoczne jest także w kolejnym źródle. W nowoasyryjskich zbiorach zaklęć można znaleźć takie królewskie złorzeczenie wobec niejakiego Bel-ețira:

„Bel-eṭir, scudzołożony jeniec (hibtu niku) - podwójnie, o wypływającym oku - podwójnie, zezowaty - podwójnie. ... Nie wypuszczę go, dopóki go nie scudzołożę" (SAA 3 30:1.7) ${ }^{11}$.

Nie ulega zatem wątpliwości, że gwałt homoseksualny miał być upokorzeniem dla przeklinanego, a dowodem tryumfu przeklinającego. Inne królewskie zaklęcie dotyczące tegoż samego Bel-ețira potwierdza takie postrzeganie homoseksualizmu:

Otwórz pojemnik na tabliczki i przeczy[taj] stelę, [określ przeznaczenie] Bel-ețira, syna Iby, jak psa. ... Niewolnik poddany Szamasz-ibniemu, syn podłego rybaka, 'nie’ [godzien] [króles`twa, zbiornik łajna Zeru-kina, nadęty, scudzołożony towarzysz Nummuraja $(\text { SAA } 3 \text { 29:1.3-4) })^{12}$.

Zatem jeśli władca chciał kogoś obrazić, to wyzywał go od najgorszych, w tym życząc mu homoseksualnego stosunku w roli podporządkowanego partnera, czyli zrównując go z kobietą, co oczywiście było obrazą dla mężczyzny. Osoba taka była przy tym określona mianem psa (kalbu). Ten termin przypomina biblijne określe-

11 Livingstone, Court Poetry, 030:1; por. Nissinen, Homoeroticism in the Biblical World, 35, przyp. 33, gdzie autor próbuje zidentyfikować Bel-ețira. Przykład tego złorzeczenia pokazuje, że w omawianych przypadkach czasownika nâku nie sposób tłumaczyć przez zwykłą formę „cudzołożyć”. Bel-ețir nie jest bowiem „cudzołożny” ani też „cudzołożący” (użyty tu jest przymiotnik nīku, pochodzący od czasownika nâku), lecz „poddany cudzołóstwu”, czyli właśnie „scudzołożony”, „zgwałcony”. Podobnie forma attikūšu lepiej oddana jest przez „scudołożę go", co zakłada użycie przemocy, aniżeli „dopuszczę się z nim cudzołóstwa”, co zakładałoby raczej zgodę obu partnerów. Z pewnością tekst mówi jednak o życzeniu gwałtu homoseksualnego, a nie o zgodnym współżyciu.

12 Livingstone, Court Poetry, 029:1,3-4. 
nie męskiej nierządnicy kultowej (keleb ) pojawiające się w Pwt 32,18-19 ${ }^{13}$. Być może mamy więc tutaj paralelę dla określenia znanego z Biblii, choć należy również zaznaczyć, że akadyjski termin kalbu był często używany dla określenia w pełni podporządkowanego, wiernego sługi/niewolnika, co także pasuje do kontekstu przekleństwa.

\section{Złorzeczenie w traktacie}

Oczywiście nie ma wątpliwości co do samego istnienia męskich prostytutek na starożytnym Bliskim Wschodzie. Jednak zawsze jest to osoba pogardzana, o niskim statusie społecznym. Takiego losu można życzyć wrogowi, np. władcy, który złamie przymierze. W traktacie zawartym przez asyryjskiego króla Aszszur-nirariego V (755-745 przed Chr.) z królem Arpadu Mati'-ilu w maledykcji znajduje się następujące przekleństwo:

Jeśli Mati'-ilu zgrzeszy przeciwko traktatowi (zawartemu) z Aszszur-nirarim, królem Asyrii, niech Mati'-ilu stanie się nierządnicą (harimtu), [jego] żołnie[rze] kobietami, niech otrzymują [podarek] na placu miasta jak jakaś nierządnica; z kraju do kraju niech będą pędzeni; niech pożycie Mati'-ilu będzie jak u muła, a jego żony będą bardzo stare. Niech Isztar, pani mężczyzn i pani kobiet, weźmie ich ukk $^{14}$, a przyniesie im hańbę. Niech gorzko zawodzą mówiąc: Zgrzeszyliśmy przeciwko traktatowi (zawartemu) z Aszszur-nirarim, królem Asyrii (SAA 2 5:8-15).

W całym ciągu złorzeczeń wobec łamiących przymierze na pierwszym miejscu pojawia się przekleństwo, mówiące, że niewierny władca ma zostać nierządnicą. Termin „nierządnica” (harimtu) odnosi się w pierwszym rzędzie do kobiet i określa zarówno zwykłe prostytutki, jak i nierządnice sakralne, często związane z kultem Isztar ${ }^{15}$. W tym jednak wypadku nie ma wątpliwości, że taką prostytutką ma zostać król, a wraz z nim wszyscy jego wojownicy (dosł. „mężczyźni”). Obok tego pozostałe przekleństwa dotyczą zupełnego zaniku potencji tak u króla, jak i u wszystkich mężczyzn. Oznacza to, że w wyniku złamania przymierza wszyscy mają stracić swą pozycję mężczyzn (dominującą) i przyjąć rolę kobiet (poddaną). Nie ulega zatem wątpliwości, że w przytoczonym tekście stosunek homoseksualny jest dla penetrowanego

13 Zob. ABD s.v. „Prostitution, B. Cultic Prostitution in OT”.

14 Wyraz „łuk” (qaštu), oprócz zwykłego znaczenia, jest także używany w odniesieniu do męskiej potencji; zob. Biggs, ŠÀ.ZI.GA, 18:3: „niech jego [koł]czan nie będzie pusty, niech jego łuk nie będzie zwiotczały!”. W kontekście omawianego złorzeczenia, które dotyczy wyłącznie sfery erotycznej, takie właśnie znaczenie „łuku” wydaje się być najwłaściwsze.

15

CAD H, 101. 
mężczyzny upokorzeniem. Z kolei ten, kto dokonuje penetracji, w ten sposób wyraża swą dominację.

\section{Zbiór wróżb šumma ālu}

Z podobną sytuacją mamy do czynienia w nowoasyryjskich tekstach wróżebnych z serii šumma ālu. Omina o charakterze seksualnym, zawarte na tabliczkach 103-104, zbudowane są w układzie binarnym, dotyczącym hierarchii (dominacja/ podporządkowanie), płci (męskie/żeńskie) i seksualności (strona penetrująca/strona pasywna ${ }^{16}$. Wśród wróżb na tabliczce 104 znajdują się następujące:

[13:] Jeśli człowiek współżyje (itẹhhe) z równym sobie (mehrǐšu) od tyłu, zostanie przywódcą wśród rówieśników i braci.

[32:] Jeśli człowiek współżyje z męską nierządnicą (assinnu), ciężki los zostanie uwolniony na niego (?).

[33:] Jeśli człowiek współżyje z dworzaninem świątynnym/pałacowym (gerseqqû),

lęki ogarną go przez cały rok, ale później go opuszczą.

[34:] Jeśli człowiek współżyje z niewolnikiem urodzonym w domu (dušmu), dopadnie go ciężki los ${ }^{17}$.

Pierwszy z cytowanych ominów pokazuje wyraźnie, że dominującą pozycję wśród innych równych mu mężczyzn (mehru „równy”, „taki sam”; w tekstach nowoasyryjskich „kolega” ${ }^{18}$ ) zajmuje ten, który jest w stanie doprowadzić do homoseksualnego współżycia. Jest ono określone w tym tekście przy pomocy powszechnie używanego czasownika țeĥu „zbliżyć się”, w kontekście seksualnym „współżyć”. Kolejne omina już nie są tak oczywiste, ponieważ osoba, która jest partnerem przy stosunku homoseksualnym należy do specyficznej grupy społecznej, niemającej równego statusu prawnego z człowiekiem wolnym. W pierwszym przypadku jest to assinnu, czyli męski czło-

16 Zob. Guinan, „Auguries of Hegemony”, 464.

17 Zachowana kopia pochodzi z czasów Aszurbanipala (669-631), jednak sam zbiór kształtował się przez wiele wieków i z pewnością jest dużo starszy. Publikacja oryginału: CT 39, pl. 44-45. Por. tłumaczenia: Guinan, „Auguries of Hegemony”, 469; Nissinen, „Are There Homosexuals”, 75; nieco wcześniejsze: Nissinen, Homoeroticism in the Biblical World, 27. Ciągle jeszcze nie ma nowego tłumaczenia i komentarza autorstwa Sally Freedman, If a City is Set on a Height. The Akkadian Omen Series Šumma Alu ina Mēlê Šakin, ponieważ ukazały się dotychczas tylko trzy tomy, które obejmują tekst do 63 tabliczki. Natomiast dawne wydanie Friedricha Nötschera z 1930 roku nie obejmowało interesujących nas tabliczek. Greenberg (The Construction of Homosexuality, 126-127) posługiwał się popularnym tłumaczeniem: Grayson Redford, Papyrus and Tablet, 149. 
nek kultowego personelu świątyni Isztar ${ }^{19}$. Z reguły jest on traktowany jako męska nierządnica, a jego status społeczny jest niski (zob. poniżej). Tekst jest niejasny, niektórzy traktują go jako omen pozytywny ${ }^{20}$, inni zaś jako negatywny ${ }^{21}$. Trudno na tej podstawie wyciągać dalej idące wnioski. W kolejnym wersie partnerem seksualnym

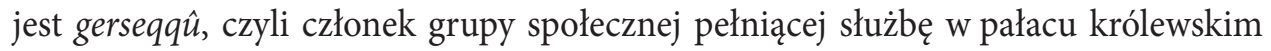
albo w świątyni, ewentualnie u jakiegoś właściciela dużej posiadłości. Nie jest to niewolnik, jednak nie ma statusu równego człowiekowi wolnemu ${ }^{22}$. Można tłumaczyć to jako „dworzanin”, „służba dworska”. Omen jest negatywny, jednak nie nazbyt dokuczliwy, zapowiadane bowiem nieszczęście mija po roku. Być może wskazuje to na pewne nadużycie ze strony sprawcy, jednak nie jest ono oceniane zbyt surowo. Wreszcie trzeci wers mówi o specyficznej kategorii niewolników, czyli takich, którzy urodzili się w domu swego właściciela. Oznacza to, że potencjalnym ojcem może być sam właściciel albo na przykład ojciec właściciela, co oznaczałoby swego rodzaju kazirodztwo ${ }^{23}$. Wydaje się, że to jest podstawą do wyraźnie negatywnego omenu, nie zaś sugestia, że „seksualny związek osłabiał autorytet pana wobec niewolnika” ${ }^{24}$. Taka interpretacja więcej mówi o współczesnym autorze aniżeli o starożytnym źródle, ponieważ najwyraźniej uznaje ona współżycie dwóch mężczyzn za przejaw bliskości i więzi pomiędzy nimi (stąd osłabienie hierarchiczności w relacji pan - niewolnik), zamiast - tak jak to widać było w poprzednich źródłach - za upokorzenie i pohańbienie jednego z nich. W takiej sytuacji współżycie homoseksualne raczej podkreślało przepaść dzielącą pana i niewolnika ${ }^{25}$. Wydaje się, że do pewnego stopnia zbiór powyższych ominów zawiera pewną ocenę moralną, choć jej treść nie jest wyrażona wprost i wymaga naszej interpretacji. Należy jednocześnie zaznaczyć, że teksty wróżebne ze swej natury nie muszą wiązać się z wartościowaniem etycznym czynów. Ich budowa jest prosta: takie-a-takie działanie oznacza takie-a-takie wydarzenie w przyszłości.

19 CAD A2, 341-342. Jest także żeński odpowiednik assinnatu.

20 Tj. człowiek zostanie uwolniony od ciężkiego losu; zob. Nissinen „Are There Homosexuals”, 75.

21 Tj. ciężki los spadnie na człowieka; zob. Guinan, „Auguries of Hegemony”, 464. Por. wahanie w pracy Phyllisa A. Birda (Faith, Feminism, and the Forum of Scripture, 160-161).

22 CAD G, 94-96. Termin ten określa obie płcie, jednak kontekst wskazuje tutaj na rodzaj męski. Zdecydowanie nie ma racji Greenberg (The Construction of Homosexuality, 127), widząc tutaj, podobnie zresztą jak w przypadku assinnu, osoby o wysokim statusie społecznym.

23 Nieco podobnie argumentował Martti Nissinen (Homoeroticism in the Biblical World, 28), który wskazywał na przynależność takiego niewolnika do rodziny.

24 Zob. Greenberg, The Construction of Homosexuality, 127; za nim rozważa taką interpretację Robert A.J. Gagnon (The Bible and Homosexual Practice, 8).

25 W tę stronę zmierzał w swej interpretacji Donald J. Wold (Out of Order, 48), jednak doprowadził ją ad absurdum, ponieważ sugerował, że współżycie z niewolnikiem byłoby umniejszeniem statusu człowieka wolnego. Jednak oznaczałoby to, że człowiek wolny nie powinien w ogóle współżyć z niewolnikami/ niewolnicami, co w oczywisty sposób jest sprzeczne ze źródłami. Wydaje się, że w takiej argumentacji pobrzmiewają echa poglądu z przełomu XIX i XX w. o wyższości klasy/rasy, której nie godzi się brudzić kontaktami z osobami niższego rzędu. W starożytnej Mezopotamii było przeciwnie: właściciel jak najbardziej miał prawo do współżycia ze swą własnością, jaką byli niewolnicy, a dzieci zrodzone ze związku z niewolnicy i pana miały nieco wyższy status niż dzieci niewolników. 


\section{Zbiory onejromantyczne}

Podobna sytuacja zachodzi w przypadku ominów sennych, jednak ich tłumaczenie jest problematyczne zarówno ze względu na zły stan zachowania tabliczek, jak i na trudność w rozumieniu kluczowego znaku UM/DUB/DíH. Wydawca tekstów wstrzymał się wprawdzie od jego tłumaczenia jako zbyt niepewnego ${ }^{26}$, jednak może on oznaczać współżycie seksualne ${ }^{27}$. Wówczas mielibyśmy tam omen dotyczący na przykład snu o współżyciu z królem („Jeśli on czyni um z królem, ręka króla pochwyci [go]”), z wysoko postawioną osobą („Jeśli on czyni um z ważną osobą, ważna osoba [...]”) albo z młodym człowiekiem („[Jeśli] on czyni um z młodym człowiekiem, będzie się martwił”). Należy jednak zaznaczyć, że większość omenów dotyczących snów o relacjach seksualnych mówi o kontaktach heteroseksualnych (np. „Jeśli on czyni um z córką króla: pomyślność przez rok"). Niestety nie sposób ustalić, czy sen o kontaktach homoseksualnych zwiastuje niepomyślność, zaś sen o kontaktach heteroseksualnych jest omenem pomyślnym, ponieważ zdecydowana większość tekstów wróżb ma uszkodzoną drugą kolumnę, przez co w ogóle nie wiadomo, co zapowiada. Jedyne co można powiedzieć na ich podstawie - przy założeniu, że UM oznacza współżycie - to fakt, że kontakty homoseksualne istniały, choć z pewnością nie w takiej formie, jaka występuje we śnie (np. współżycie z królem!). Nawet jednak w takich wróżbach, opartych na snach, zawsze jest mowa o współżyciu mężczyzn. Brak jest choćby jednego przykładu relacji lesbijskich.

\section{Męska prostytucja kultowa}

W powyżej przedstawionych tekstach pojawiał się termin assinnu. Warto przyjrzeć mu się bliżej oraz podobnym jemu terminom kurgarrû, kalû i kulu’ư ${ }^{28}$. Osoby określane w ten sposób są zawsze związane z kultem Inanny/Isztar, czyli wojowniczej bogini miłości, płodności i seksu. Sama bogini - mimo bez wątpienia płci żeńskiej - łączy w ten sposób cechy właściwe kobietom (płodność) i mężczyznom (wojowniczość). Dlatego też także jej służba cechuje się pomieszanymi funkcjami kulturowymi mężczyzny i kobiety. Już mitologiczna opowieść o początkach assinnu, kalû i kurgarrû wskazuje na ich niejasną płciowość. Terminy te pojawiają się w sumeryjskim i aka-

26 Oppenheim, The Interpretation of Dreams, 290-291, 333-334 (K 6705, 6768, 6824); Oppenheim, „Divination and Celestial Observation", 156-157 (K 9169, 13642).

27 Riekele Borger (Assyrisch-babylonische Zeichenliste, 95 [134]) łączy ten znak z czasownikiem teh $\hat{u}$.

28 Szersze omówienie tych terminów oraz ich funkcji: Bottéro - Petschow, „Homosexualität”, 463-466; Maul, „kurgarrû und assinnu”, 159-172; Nissinen, Homoeroticism in the Biblical World, 29-36; Teppo, „Sacred Marriage”, 75-92; Peled, „assinnu and kurgarrû Revisited”, 283-297; a szczególnie Peled, Masculinities and Third Gender, 91-202, tam także literatura. 
dyjskim micie o zejściu Inanny/Isztar do świata podziemnego i określają osoby stworzone przez Enki/Ea w celu uratowania bogini, która została uwięziona (czyli umarła) w podziemnym królestwie Ereszkigal. Ponieważ droga do świata podziemnego jest dla każdego człowieka drogą bez powrotu, zatem bóg mądrości tworzy istoty (odpowiednio w wersji sumeryjskiej kurgarra i galaturra ${ }^{29}$, zaś w akadyjskiej assinnu), które z racji niejasnego statusu, nie mogą być zakwalifikowane jako kobieta albo mężczyzna i dzięki temu mogą one opuścić świat umarłych ${ }^{30}$. W kulcie assinnu, kalû, kurgarrû i kulu’u spełniali różne funkcje: byli tancerzami, muzykami i śpiewakami świątynnymi. Ubierali się przy tym jak kobiety i nosili makijaż. W tańcu posługiwali się bronią (szczególnie kurgarrû w celu samookaleczenia[?] samokastarcji[?]), ale jednocześnie mogli trzymać wrzeciono. Określani byli jako kochankowie bogini i brali udział w rytuałach związanych z erotyką (np. w rytuale przeciwko rywalowi o wdzięki kobiety). Niekiedy pełnili także funkcje prorockie, pomagali w leczeniu, wznosili lamentacje. Wymienione funkcje wskazują na połączenie ról męskich i kobiecych, charakterystyczne dla bogini Isztar. Wydaje się, że najpełniej oddaje je przeciwstawny charakter assinnu i kurgarrû, z których pierwszy miał funkcje wyraźnie kobiece, natomiast drugi wykazywał cechy wojownicze ${ }^{31}$. Te różne kategorie męskiego personelu kultowego wymieniane są jednocześnie z kobiecą służbą w świątyni (harimtu, kezertu, sekretu, šamhatu), która pełniła między innymi funkcję nierządnic sakralnych. Stąd przyjmuje się, że przynajmniej niektórzy z nich także brali udział w prostytucji sakralnej w roli biernych mężczyzn/eunuchów(?). Dobrze oddaje to fragment eposu o bogu Erra, pochodzący z VIII w. przed Chr.:

Co do Uruk, siedziby Anu i Isztar, miasta nierządnic sakralnych, kurtyzan i prostytutek świątyn[nych] (āl kezrêti, šamhātu u harìmat [ī]),

które Isztar pozbawiła mężów i wzięła do siebie:

Sutejczycy i Sutejki wydali okrzy[k].

Prowadzą z E-anny tancerzy (kurgarrû) i męskie prosty[tutki] (isin[nī]),

którym Isztar zamieniła męskość na kobie[cość], aby ludziom zaszczepić bojaźń,

(a także) nosicieli mieczy, brzytew, noży i ostrzy krzemiennych,

którzy czynią to, co zakazane, by zadowolić Iszta ${ }^{32}$ (IV:52-57) $)^{33}$.

Można je oddać jako kurgarrû i młody kulu’u. Są one tworzone z brudu spod paznokcia boga, co wskazuje na niską pozycję społeczną.

30 Zob. dla tekstu sum.: ETCSL 1.4.1; dla tekstu akad.: Borger, Babylonisch-Assyrische Lesestücke, II, 86-93. Najpopularniejsze tłumaczenia obu tekstów: ANET 52-57; 106-109; Jacobsen, The Harps that Once, 205-232; CoS I, 381-384; TUAT AF III, 458-495, 760-766; Foster, Before the Muses, 498-505. Thumaczenia polskie: Szarzyńska, Eposy sumeryjskie, 83-101; Drewnowska-Rymarz et al., Mity akadyjskie, 86-91.

31 Peled, „assinnu and kurgarrû Revisited”, 283-297.

32 Ostatni wers brzmi dosłownie: „Którzy zjadają tabu (asakku), by zadowolić wątrobę Isztar”. Termin asakku oznacza to, co jest zakazane ze względów kultowych. Wyrażenie „zjadać asakku” oznacza „złamać tabu, zakaz" i wywodzi się z zakazów pokarmowych, jednak powszechnie oznacza złamanie każdego rodzaju zakazu; zob. CAD A2, 326-327. Wątroba jest z kolei siedzibą uczuć i emocji (podobnie jak w Biblii, często w tej funkcji pojawiają się nerki). 
Tekst nie jest jasny co do funkcji konkretnych wymienionych grup, a tłumaczenia ich nazw są przybliżone. Można jednak być pewnym, że to, co robiła grupa assinnu, kurgarr $\hat{u}, k a l \hat{u}$ i kulu’u, przekraczało normy przyjęte w społeczeństwie. Nie wiemy, czy polegało to tylko na noszeniu szat kobiecych przez mężczyzn, czy też na samookaleczaniu się, być może samokastracji, na co może wskazywać używanie ostrych narzędzi podczas rytuału ${ }^{34}$. Nie ulega jednak wątpliwości, że elementem ich powinności kultycznych były także stosunki homoseksualne. Na przykład nazwa kapłanów kalû, zwykle tłumaczona jako „śpiewacy wznoszący lamentacje”, zapisywana była między innymi przy pomocy znaków uš.ku, czyli sumerogramów Gì̌ oraz DúR, oznaczających odpowiednio „penis” i „odbyt” ${ }^{35}$. Sama nazwa pokazuje więc jasno, że nie chodziło tu tylko o śpiewanie. Na związek kalû z homoseksualną prostytucją sakralną wskazuje także przysłowie: „Śpiewak lamentacji wytarł swój odbyt: „Nie można usunąć tego, co należy do mej pani Inanny«" $(2.100)^{36}$. Z kolei nazwę assinnu/kulu’u zapisywano sumerogramami UR i MUNUs, co najczęściej tłumaczy się jako „on-kobieta”. Nazwa taka wyrażała podwójną płciowość męsko-żeńską. Inną możliwością jest odczytanie znaku ur jako „pies”, co oznaczałoby nazwanie

33 Zob. najnowszą edycję tekstu eposu: Taylor, The Erra Song, 375-376 (kurgarrû i assinnu odpowiednio jako „członkowie personelu kultowego i męskie prostytutki”. Inne najpopularniejsze tłumaczenia: CoS I, 413 („chłopcy na imprezę, świętujący ludzie”); TUAT AF III, 795 („kultowi śpiewacy i tancerze”); Foster, Before the Muses, 904 („aktorzy i śpiewacy”, choć autor widzi w tekście zarówno żeńskie, jak i męskie prostytutki kultowe). W tłumaczeniu polskim kurgarrû i assinnu oddani są jako „eunuchy i przebierańcy”; zob. Drewnowska-Rymarz et al., Mity akadyjskie, 105. Sugeruje to rozumienie kurgarrû jako kastratów, zob. niżej. Na związek z nierządem sakralnym wskazuje także tekst zestawiający obok siebie kulu’u i harimtu (CAD K, 529)

34 Na samookaleczanie zdaje się wskazywać tekst sumeryjskiego hymnu króla Iddin-Dagana: „Ze sztyletami w swych rękach ... kurgarra wstępują przed nią, czystą Inannę. Ci, którzy unurzali swe miecze w rozlanej krwi, gdy wstępowali przed nią, czystą Inannę. Krew rozlewa się na podstawę tronu" (zob. ETCSL 2.5.3.1:76-80). Może to wprawdzie być krew ofiar zwierzęcych, jednak należy zauważyć, że kurgarrû pojawiają się w asyryjskim wykazie żeńskiej służby pałacowej, mimo swego męskiego rodzaju (SAA 7 24:11.24). Ewentualne samookaleczenie przywodzi oczywiście na myśl małoazjatycki kult Kybele i Adonisa, który z pewnością nawiązywał do kultu Isztar i Dumuziego oraz kapłanów galli, dokonujących samokastracji w ramach rytuału. Należy pamiętać, że gdy Isztar w micie schodzi do podziemia, gdzie umiera, cała przyroda (w tym zwierzęta i ludzie) traci swą płodność i pogrąża się w żałobie. Taki kontekst mityczny sugeruje, że podczas rytuału mogło dochodzić do samokastracji, a eunuchowie pełnili później pasywną rolę we współżyciu homoseksualnym. Nie ulega przy tym wątpliwości sam fakt istnienia kastratów (ša rēši ) w społeczeństwie mezopotamskim i ich bliski związek z kultem bogini Isztar. Na swych pieczęciach są oni często przedstawiani jako oddający cześć właśnie Isztar lub jej symbolom; zob. Nissinen, Homoeroticism in the Biblical World, 31; Peled, Masculinities and Third Gender, 203-238.

35 Zob. Borger, Assyrisch-babylonische Zeichenliste, 110 (211), 186 (536).

36 Zob. ETCSL 6.1.02:165-166. W starszym wydaniu nieco inaczej oddawano problematyczny czasownik z drugiego wersu: „Nie można cieszyć się z tego, co należy do mej pani Inanny” (zob. Gordon, The Sumerian Proverbs, 248-249). Można domyślać się, że „tym, co należy do Inanny” (dosł. „rzeczą") jest nasienie pozostałe w odbycie kalû po stosunku homoseksualnym. 
mężczyzny właśnie psem ${ }^{37}$. Może być to podobne do - wspominanego już powyżej w przekleństwie dotyczącym Bel-ețira - określenia mianem „psa” męskiej prostytutki. Takie odczytanie sugerowałoby funkcję męskiej prostytutki świątynnej, która podczas stosunku pełni rolę kobiety. Oczywiście jednocześnie wskazywałoby to na niski status społeczny osoby, ponieważ określenie mężczyzny zarówno jako psa i jako kobiety musiało być traktowane jako uwłaczające.

Z pewnością żaden spośród assinnu, kurgarrû, kalû czy kulu’u nie był traktowany w społeczeństwie jako pełnoprawny mężczyzna. Jeśli chciało się kogoś obrazić, można było o nim powiedzieć: „On jest kulu’u, a nie mężczyzną”38. Brak jest wzmianek, by członkowie tych grup mieli żony, choć z rzadka są wspominane ich dzieci, nie wiadomo jednak, czy naturalne (sprzed wstąpienia na służbę Isztar?), czy też adoptowane (jak to było w przypadku kapłanek sekretu czy też dworzan/dwórek gerseqqû, którzy własnych dzieci mieć nie mogli). Nie ulega także wątpliwości, że współżycie z nimi miało również wymiar sakralny, podobnie zresztą jak współżycie z żeńskimi nierządnicami świątynnymi. Źródła wskazują, że do takich kontaktów dochodziło nie tylko na terenie świątynnym, ale także w karczmach, które od dawna pełniły także funkcję domów publicznych ${ }^{39}$. Zatem mowa jest tu o wyjątkowej formie kultu, połączonej z prostytucją, gdzie nie było stałych partnerów, zaś seks był także formą oddania czci bóstwu. Dotyczyło to zarówno aktywnego podczas stosunku mężczyzny, który w ten sposób chwilowo włączał się w kult Isztar, jak i ze strony mężczyzny (eunucha[?]) pasywnego, który - będąc członkiem personelu świątynnego - dokonywał wyboru całej swej drogi życiowej. Należy zaznaczyć, że poza kontekstem kultowym assinnu, kurgarrû, kalû czy kulu’u budzili raczej strach, a nawet odrazę. W źródłach pojawiają się niekiedy jako podejrzani o zabójstwa czy kradzieże ${ }^{40}$.

\section{Epos o Gilgameszu}

Innym źródłem, w którym niektórzy dostrzegają przekaz na temat kontaktów homoseksualnych w Mezopotamii, jest powszechnie znany epos o Gilgameszu. Analizowane w tym kontekście są relacje pomiędzy Gilgameszem a Enkidu ${ }^{41}$. Pierwszym

37 Zob. Borger, Assyrisch-babylonische Zeichenliste, 197 (575); Bottéro - Petschow, „Homosexualität”, 465. Znaczenie „pies” jest zdecydowanie częstsze i stosowane w szerszym przedziale czasowym; zob. EPSD s.v. „UR [dog]”, 725 przykładów, głównie od okresu Ur III do okresu nowoasyryjskiego, zaś UR [he] tylko 262 przykłady niemal wyłącznie z okresu starobabilońskiego.

38 Weidner, „Aus den Tagen”, 3.

39 Nissinen, Homoeroticism in the Biblical World, 33.

40 Zob. szerzej Teppo, „Sacred Marriage”, 87-88.

41 Np. Horner, Jonathan Loved David, 15-19 (autor ten widział zresztą relacje homoseksualne nie tylko między Gilgameszem i Enkidu, ale także między Dawidem i Jonatanem, Noemi i Rut itd.); Greenberg, The Construction of Homosexuality, 112-113; Halperin, One Hundred Years of Homosexuality, 75-87; 
przytaczanym w tym kontekście fragmentem jest sen opowiadany przez Gilgamesza swej matce przed przybyciem Enkidu:

Gilgamesz w Uruk miał widzenia senne:

Gilgamesz powstał, by opowiedzieć sen, mówiąc do swojej matki:

„Matko, tej nocy miałem sen -

ukazały mi się gwiazdy z nieba,

jakby kamienie spadały przede mną.

Schyliłem się, by podnieść jedną z nich, lecz była za ciężka dla mnie.

Chciałem ją toczyć, lecz nie mogłem jej ruszyć.

Mieszkańcy Uruk stali wokół,

[cały kraj zgromadził się] przy niej.

Tłum [tłoczył się] przed [nią],

[rzesza ludzi] cisnęła się wokół niej.

Całowali jej stopy [jak małemu] dziecku.

[Ukochałem ją] jak żonę i pieściłem, i obejmowałem ją.

[Podniosłem ją i] złożyłem u [twych] stóp,

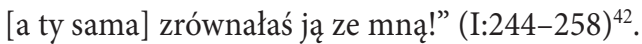

Odpowiadając, matka Gilgamesza wyjaśniła mu sen:

Przyjdzie do ciebie potężny towarzysz, wybawca (swego) przyjaciela.

Jest on najmocniejszy w kraju, posiada siłę;

jego siła jest tak wielka jak skały niebiańskiej.

Będziesz go kochał jak żonę, pieszcząc go i obejmując;

on, będąc mocny, często będzie cię wybawiał (I:268-272) ${ }^{43}$.

Tekst następnie powtarza się, z tym że zamiast „gwiazdy”, we śnie jawi się Gilgameszowi „siekiera”. Ostatecznie Gilgamesz cieszy się, mówiąc:

Otrzymam przyjaciela, doradcę,

przyjaciela, doradcę otrzymam! ${ }^{14}$ (I:296-297).

Leick, Sex and Eroticism, 254-269; Nissinen, Homoeroticism in the Biblical World, 20-24; Wold, Out of Order, 49-50; Gagnon, The Bible and Homosexual Practice, 10-11.

42 Zob. podstawowe wydanie eposu: George, The Babylonian Gilgamesh Epic, 553. Tłumaczenie polskie za: Tronina, Epos o Gilgameszu, 43. Por. Łyczkowska - Puchta - Kapełuś, Epos o Gilgameszu, 9. Inne popularne tłumaczenia: ANET 76; TUAT AF III, 679-680.

43 Tronina, Epos o Gilgameszu, 44.

44 Tronina, Epos o Gilgameszu, 45. 
Nie ulega wątpliwości, że oba sny zapowiadają przybycie Enkidu, który zresztą już w tekście eposu się pojawił. Dla badaczy widzących związek homoseksualny łączący Gilgamesza i Enkidu kluczowe znaczenie mają słowa: „Będziesz go kochał jak żonę, pieszcząc go i obejmując". Oczywiście zawierają one w sobie element erotyczny. Jednak interpretacja widząca w obu bohaterach pierwszą gejowską parę napotyka istotne problemy. Po pierwsze mowa jest o śnie, zatem mamy do czynienia z pewną wróżbą, zapowiedzią. Powyżej już przedstawiane były przykłady ominów sennych, np. mówiące o współżyciu z królem (inne mówią o współżyciu z bogiem itd.). Czy jednak oznacza to, że ktoś, kto zgłaszał się do wróżbity, opisując taki sen, rzeczywiście doprowadził do homoseksualnego stosunku z królem albo z bóstwem? Odpowiedź jest oczywista - nie. Z identyczną sytuacją mamy do czynienia i tutaj. Omen senny nie opisuje rzeczywistości, ale jest jej umowną zapowiedzią, wymagającą wytłumaczenia przez osobę wykwalifikowaną, w tym wypadku przez matkę Gilgamesza Ninsun, która była boginią. Gilgamesz doskonale rozumie wytłumaczenie snu, ponieważ z radością wykrzykuje „Otrzymam przyjaciela, doradcę!”. Nie określa Enkidu żadnym sformułowaniem, które mogłoby sugerować jakiś związek homoseksualny. Co jeszcze ważniejsze, obaj bohaterowie są wyraźnie przedstawieni jako osoby heteroseksualne. Gilgamesz obficie korzysta z ius primae noctis wobec młodych żon swych poddanych, zaś Enkidu oddaje się namiętnej miłości z Szamchat, którą tekst określa jako harimtu, czyli „nierządnicę”. Żaden z kolejnych fragmentów tekstu nie wskazuje na związek homoseksualny pomiędzy Gilgameszem a Enkidu, chyba że ktoś chciałby wyraźnie nadinterpretować opis, gdy obaj bohaterowie, zmęczeni po walce, godzą się i obejmują oraz na znak przyjaźni trzymają za ręce (II:182-183). Podobnie starobabilońska wersja tekstu, przechowywana obecnie w Yale, mówi o relacji pomiędzy bohaterami: „Pocałowali się i zawarli przyjaźn” (I:18-19) ${ }^{45}$. Gdyby tego typu sygnały traktować jako przejaw związku homoseksualnego, wówczas wszystkich mężczyzn na Bliskim Wschodzie należałoby dziś nazywać gejami, ponieważ powszechny jest wśród nich pocałunek na powitanie ${ }^{46}$.

Wreszcie całe opowiadanie zwraca uwagę na równorzędną pozycję Gilgamesza i Enkidu, co jest podkreślone przez „remis” w ich pojedynku. Natomiast wszystkie teksty mezopotamskie wspominające o współżyciu homoseksualnym wyraźnie wskazują na nierówną pozycję obu partnerów, z wyraźnym zaznaczeniem dominacji jednego i poddania drugiego. Z pewnością taka sytuacja nie ma miejsca w Eposie o Gilgameszu i nie sposób widzieć w głównych bohaterach pary gejów ${ }^{47}$.

45 George, The Babylonian Gilgamesh Epic, 196-197. Por. Łyczkowska - Puchta - Kapełuś, Epos o Gilgame$s z u, 72$; Tronina nie tłumaczy innych zachowanych fragmentów poza standardową wersją eposu.

46 Przemiany etniczne nic tutaj nie zmieniły, podobnie było w starożytności, por. pocałunek Judasza witającego Jezusa.

47 Przeciwko takiemu pojmowaniu relacji między Gilgameszem i Enkidu opowiadają się: Wold, Out of Order, 49-50; George, The Babylonian Gilgamesh Epic, 452-454; Tronina, Epos o Gilgameszu, 132. Charakterystyczne jest, że Krystyna Łyczkowska nawet nie wspomina o Gilgameszu i Enkidu w swym 


\section{Inne błędne przykłady}

Nie można też doszukiwać się homoseksualizmu, naciągając inne źródła. Dobrym przykładem takiego nieuzasadnionego podejścia jest apodyktyczne stwierdzenie Davida F. Greenberga, że zarówno król Zimri-Lim z Mari (1775-1761 przed Chr.), jak i król Hammurabi z Babilonu (1792-1750 przed Chr.) mieli swych męskich kochanków ${ }^{48}$. Gdy jednak lepiej przyjrzeć się źródłom przywoływanym przez Greenberga, okazuje się, że żona Zimri-Lima w liście przestrzegającym go przed możliwą rebelią pisze między innymi: „Strzeż się! Otocz się sługami, swymi zaufanymi, których kochasz! Niech oni stoją (przed tobą) i niech cię chronią! Nie wychodź samemu!"49. Z pewnością tekst nie mówi o jakichkolwiek męskich kochankach, ale o zaufanych sługach króla, mających go bronić przed niebezpieczeństwem. Nie można budować zupełnie sprzecznej z całością źródła interpretacji opartej na jednym słowie („kochasz"). Miłość między mężczyznami pojawia się w listach z Mari w zupełnie nieseksualnym kontekście, choćby w typowym rozpoczęciu listu skierowanym do skryby, który miał list odczytać adresatowi: „Do X mów! Y, który cię kocha, mówi...” ${ }_{50}$. Nie sposób przecież twierdzić, że wszyscy nadawcy i adresaci tych listów byli kochankami. Nie można tego twierdzić także o autorze i odbiorcy następującego listu: „[Do] Aszquduma mów! Hulalum (mówi): „Niech Szamasz i Marduk darzą cię zdrowiem przez długi czas! [Wśród] naszych braci, (ilu) ich jest, my się kochamy [i] nie ma nikogo, kto kocha mnie tak, jak ty! [I] nie ma nikogo, kto kocha ciebie, jak ja!«"'s1. Jednak ciąg dalszy tego listu bynajmniej nie mówi o miłości między dwoma mężczyznami, ale o... setkach owiec i o handlu cyną! Ckliwo-pompatyczny początek listu jest typowy dla stylu listów z południa Babilonii w tym okresie i z pewnością nie ma żadnego związku z homoseksualizmem. Argumentację Greenberga zupełnie dyskwalifikuje jego wzmianka o kochanku Hammurabiego. Autor ten powołuje się przy tym na cytowany już artykuł William L. Morana. Jednak rzeczony tekst wspomina doskonale znany fragment z prawa Hammurabiego, w którym jest mowa o miłości Hammurabiego do E-sagili, czyli do... świątyni Marduka w Babilonie! $!^{52}$

rozdziale pracy poświęconej miłości i seksowi na starożytnym Bliskim Wschodzie (Szarzyńska et al., Miłość i seks, 45-83).

48 Greenberg, The Construction of Homosexuality, 126. Autor ten odwołuje się przy tym do niżej cytowanego artykułu Williama L. Morana, choć nie podaje stron.

49 Moran, „New Evidence from Mari”, 30-31; zob. także: Heimpel, Letters to the King of Mari, 260 (26.213).

50 Np.: Heimpel, Letters to the King of Mari, 189 (26.24); 208 (26.78); 294 (26.309); 307 (26.335); 308 (26.340); 407 (25.538); 409 (26.545); 410 (26.549, 26.550); 518 (FM 2.61).

51 Heimpel, Letters to the King of Mari, 206-207 (26.75).

52 Kodeks Hammurabiego XLVIII:1-2. Zob. Richardson, Hammurabi's Laws, 122-123; por. najnowsze polskie tłumaczenie: Tyborowski, Prawa Hammurabiego, 159. 


\section{9. Źródła ikonograficzne}

Na koniec warto wspomnieć o źródłach ikonograficznych wskazywanych jako przedstawienia aktów homoseksualnych ${ }^{53}$. Niestety praktycznie wszystkie przywoływane $\mathrm{w}$ literaturze przykłady to małe plakietki terakotowe, przedstawiające coitus a tergo. Zwykle jednak widać na nich wyraźnie mężczyznę i kobietę, przy czym najczęściej kobieta podczas stosunku pije przez rurkę jakiś napój z naczynia. Czasami w scenie pojawiają się jakieś instrumenty muzyczne. Niekiedy, ze względu na małe wymiary i dość prostą formę plakietek, trudno jest określić płeć przedstawionych osób. Warto zauważyć, że nawet gdy określenie płci osoby pasywnej jest utrudnione, to jednak zawsze jest ona przedstawiana bez brody typowej dla przedstawień mężczyzn. Podobny typ przedstawień, ukazujący coitus a tergo, znany jest z pieczęci stemplowych i cylindrycznych z okresów Uruk, Dżamdat Nasr oraz wczesnodynastycznego, gdzie także - o ile można rozpoznać płeć - mamy do czynienia z mężczyzną i kobietą ${ }^{54}$. Biorąc pod uwagę powtarzający się schemat przedstawień, należy przyjąć, że plakietki przedstawiają współżycie heteroseksualne ${ }^{55}$. Typowe przykłady ukazano poniżej.

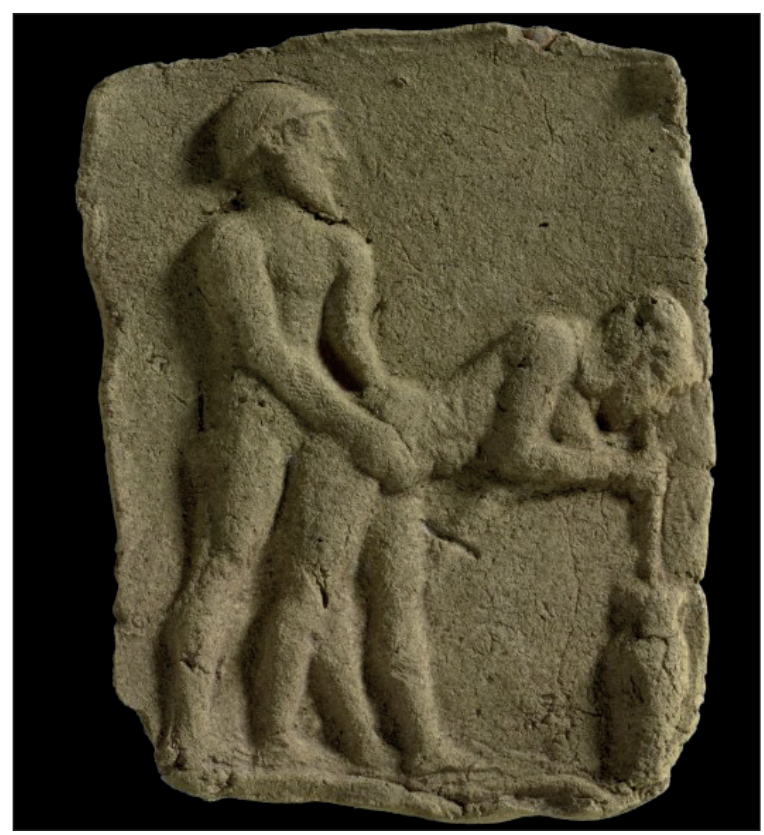

Fig. 1. Gliniana plakietka z okresu starobabilońskiego. Berlin VA 06214.

(c) Staatliche Museen zu Berlin - Vorderasiatisches Museum. Zdjęcie: Olaf M. Tessmer.

Zob. Bottéro - Petschow, „Homosexualität”, 460.

Zob. Winter, Frau und Göttin, 340-344.

55 Winter, Frau und Göttin, 349. 


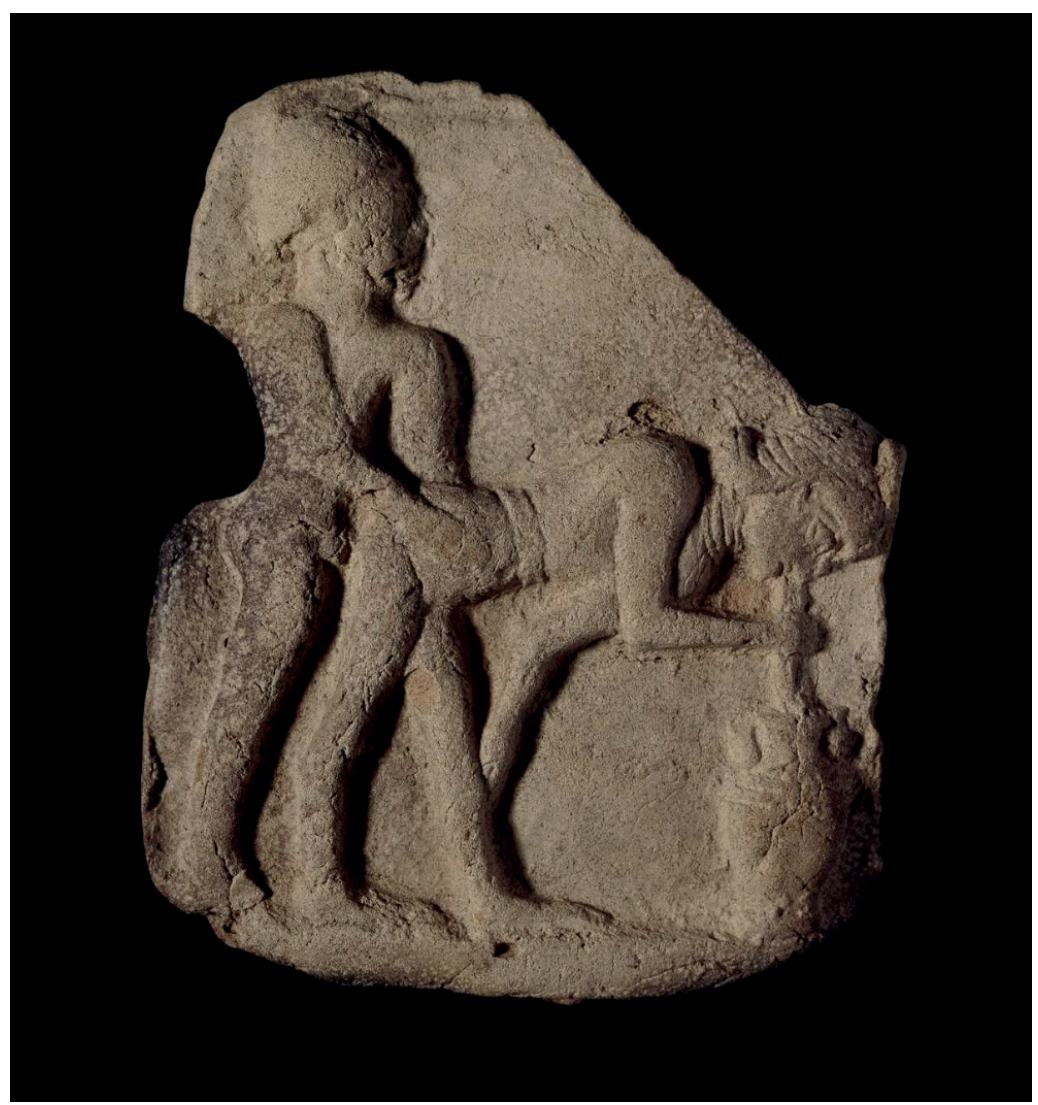

Fig. 2. Gliniana plakietka z okresu starobabilońskiego. British Museum 116731. (c) The Trustees of the British Museum

\section{0. Źródła hetyckie}

Poza Mezopotamią niemal brak jest wzmianek o zachowaniach homoseksualnych na starożytnym Bliskim Wschodzie (pomijając Egipt). Jedynie w prawach hetyckich pojawia się informacja o takim zachowaniu, ale w kontekście kazirodczego współżycia z własnym dzieckiem, co oczywiście jest karane:

\$189: Jeśli człowiek współżyje z własną matką - jest to niedozwolona relacja seksualna; Jeśli człowiek współżyje z własną córką - jest to niedozwolona relacja seksualna; Jeśli człowiek współżyje z własnym synem - jest to niedozwolona relacja seksualna (CTH 292) ${ }^{56}$.

Roth, Law Collections, 236. 
W źródłach hetyckich być może mamy także do czynienia ze swego rodzaju magicznym leczeniem homoseksualizmu w przypadku mężczyzny przyjmującego pasywną rolę we współżyciu. Taką sugestię, odnoszącą się do tekstu tzw. Rytuału Paskuwatti (CTH 406), uważanego dotychczas raczej za rytuał przeciwko impotencji, zgłosił niedawno Jared L. Miller ${ }^{57}$. Podczas takiego terapeutycznego rytuału należało przez kilka dni wzywać boginię Ulilijaszszi. Następnie badane były sny pacjenta. Jeśli śniła mu się bogini bądź nawet współżycie z nią - był to korzystny znak. Na koniec pacjent miał przejść przez bramę z trzciny, co miało zapewnić mu oczyszczenie. Jeśli przyjąć tradycyjną interpretację, wówczas chory miałby odzyskać męską potencję. Jeśli natomiast przyjąć ostatnio sugerowane rozwiązanie, wówczas pacjent miałby pozbyć się swych zniewieściałych cech i odzyskać męską rolę w społeczeństwie. Nie ulega wątpliwości, że w takiej interpretacji pasywna rola we współżyciu homoseksualnym była uważana za niewłaściwą dla mężczyzny.

Poza tym brak jest jakichkolwiek wzmianek w źródłach hetyckich. Milczenia źródeł nie można wszakże interpretować jako pełnej akceptacji dla zachowań homoseksualnych ${ }^{58}$. Raczej należy przyjąć, że tego typu praktyka nie występowała (zob. szerzej we wnioskach). Podobnie jest np. w Ugarit, gdzie w źródłach jest mowa o różnego rodzaju zachowaniach i wykroczeniach seksualnych, jednak żaden przykład zachowań homoseksualnych się nie pojawia ${ }^{59}$.

\section{Wnioski}

Podsumowując powyższy przegląd źródeł mezopotamskich, należy stwierdzić, że pojawiają się w nich wzmianki o zachowaniach homoseksualnych, choć są one stosunkowo rzadkie. Istotniejsze jest jednak, że zachowania takie są ograniczone do dwóch typów. Pierwszy z nich to relacja mężczyzny dominującego i podporządkowanego. Mężczyzna, który dokonuje penetracji jest postrzegany jako silny i nadający się na przywódcę. Mężczyzna odgrywający w relacji rolę kobiecą jest traktowany jako nie-mężczyzna i traci swą pozycję społeczną. Wydaje się, że w przypadku nierównoprawnych członków społeczeństwa (służba, niewolnicy) stosunki homoseksualne są możliwe, a im większa różnica statusu społecznego, tym bardziej są one akceptowalne, oczywiście z właścicielem jako osobą dominującą. W przypadku skrajnym,

57 Miller, „Paskuwatti’s Ritual”, 83-89; HPM 406. Najnowsze tłumaczenie tekstu zob. Mouton, Rituels, mythes et prières hittites, 230-251.

58 Wbrew sugestii D.J. Wold (Out of Order, 54).

59 Nie sposób widzieć lesbijskiej pary w KTU 1.23:31-32, 35-36. Wbrew dawnemu, niezbyt szczęśliwemu tłumaczeniu, mówiącemu o dwóch kobietach poruszających się w górę i w dół (zob. Gibson - Driver, Canaanite Myths and Legends, 125), zapewne mowa jest o wznoszącym się członku boga Ila (zob. Park, „El's member in KTU 1.23”, 617-627). 
przy pokonaniu wroga, wprost można oczekiwać, że triumfator „scudzołoży” przegranego, co będzie dopełnieniem zwycięstwa jednego i klęski drugiego z nich. Los biernego partnera może być przekleństwem używanym w złorzeczeniach. W związku z tym za niegodziwe uznaje się traktowanie osoby o równym statusie społecznym jako partnera biernego, a nawet sugerowanie, że mógł on pełnić taką rolę.

Drugi typ zachowania homoseksualnego wiąże się z kultem bogini Inanny/Isztar. Jest on ograniczony do grupy męskiego personelu świątynnego, noszącego nazwy assinnu, kurgarrû, kalû i kulu’u. Ten typ zachowań jest o tyle podobny do pierwszego, że także i w tym przypadku mężczyźni (kastraci[?]), będący bierni podczas stosunku, nie mają w społeczeństwie pozycji równorzędnej z mężczyzną dokonującym penetracji, lecz ich status jest wyraźnie niższy. Jednak poprzez fakt, że w ich przypadku akt homoseksualny jest jednocześnie formą kultu, nie są z tego społeczeństwa wykluczeni. Stanowią oni jego niewielką, niższą od wolnych mężczyzn warstwę, jednak mieszczą się w nim, stanowiąc jego specyficzny element. Jest on podobny w wielu aspektach do pozycji żeńskich prostytutek świątynnych. Obok sakralnej prostytucji homoseksualnej do obowiązków członków wymienionej grupy należały inne czynności kultowe, takie jak: śpiew, taniec, niekiedy prorokowanie, pomoc w leczeniu. Ubierali się oni przy tym i nosili makijaż na sposób kobiecy.

Całość źródeł mezopotamskich trafnie podsumowuje Martti Nissinen ${ }^{60}$. Według niego w starożytnej Mezopotamii nie ma homoseksualizmu w naszym tego słowa znaczeniu, choć jest tam miłość (niefizyczna) między mężczyznami, jest seks homoseksualny pod przymusem, są także przypadkowe kontakty homoseksualne, szczególnie w ramach kultu Inanny/Isztar. Należy zaznaczyć, że podstawową cechą aktu homoseksualnego w oczach mieszkańców Mezopotamii jest nierównorzędność partnerów, z wyraźnym zaznaczeniem dominacji jednego z nich. Żadne ze źródeł nie wspomina o jakichkolwiek, mniej lub bardziej trwałych, związkach homoseksualnych pomiędzy mężczyznami. Nie można przy tym wysnuwać wniosku, że skoro źródła o takich relacjach nie wspominają, to były one zapewne normą, po prostu oczywistością, i stąd brak jest wzmianek o nich. Trudno także przyjąć, że ze względu na brak wzmianek o parach gejów, nic na ten temat nie można powiedzieć, w tym wykluczyć ich istnienia. Źródła mezopotamskie wielokrotnie i w różnych układach opisują współżycie heteroseksualne (z małżonką, z niewolnicą, cudzołóstwo, gwałt, pomiędzy ludźmi, pomiędzy bogami itd.). W żaden sposób nie wzdragają się także wspominać o relacjach homoseksualnych, nie jest to temat tabu, choć z pewnością daleki od powszechności. Źródła ograniczają się jednak do wymienionych powyżej dwóch typów (pohańbienie, prostytucja sakralna). Nie sposób przyjąć, że z niewiadomych przyczyn źródła przemilczały istnienie par gejów, czyli domniemany trzeci typ (równorzędni partnerzy). Takie założenie, oparte na wnioskowaniu z milczenia źródeł, byłoby równie prawdopodobne, jak przyjęcie, że wprawdzie źródła nie wspo-

Nissinen, „Are There Homosexuals”, 76. 
minają nam o demokracji parlamentarnej albo o ruchu feministycznym w starożytnej Mezopotamii, ale ponieważ nie zaprzeczają temu wprost, to nie można wykluczyć ich istnienia. Należy zatem przyjąć, że żadnej innej formy relacji homoseksualnych poza pohańbieniem i prostytucją sakralną starożytna Mezopotamia nie znała, ze względu na swój kulturowy wzorzec męskości ugruntowany w patriarchalnym społeczeństwie. W ten sposób wyraźnie różniła się od współczesnego pojmowania homoseksualizmu. Warto także zaznaczyć, że żadne źródło bliskowschodnie nie wspomina o relacjach lesbijskich.

W kontekście przedstawionych źródeł należy rozumieć przytoczone na wstępie biblijne zakazy praktykowania homoseksualizmu zawarte w Księdze Kapłańskiej. Można przyjąć, że taki zakaz nawiązywał do znanych w Izraelu form homoseksualizmu praktykowanych w sąsiedniej, a zarazem bardziej rozwiniętej kulturze mezopotamskiej. Oznacza to, że Biblia zakazuje ukazywania swej dominacji poprzez wymuszone współżycie/gwałt na słabszym męskim partnerze (Kpł 18,22). Warto także zaznaczyć, że w żadnym z biblijnych złorzeczeń nie pojawia się życzenie gwałtu homoseksualnego. Oczywiście Biblia zakazuje także dobrowolnych kontaktów homoseksualnych (Kpł 20,13), ponieważ - jak wskazują źródła mezopotamskie - kontekst religijny takiego współżycia był jednoznaczny. Oznaczałoby to związek z kultem innego boga, a raczej bogini, czyli odwrócenie się od Jahwe.

\section{Bibliografia}

Biggs, R.D., ŠÀ.ZI.GA. Ancient Mesopotamian Potency Incantations (Texts from Cuneiform Sources 2; Locust Valley, NY: Augustin 1967).

Bird, Ph.A., Faith, Feminism, and the Forum of Scripture. Essays on Biblical Theology and Hermeneutics (Eugene, OR: Cascade Books 2015).

Borger, R., Assyrisch-babylonische Zeichenliste (Alter Orient und Altes Testament 33; Kevelaer:

Butzon \& Bercker - Neukirchen-Vluyn: Neukirchener 1978).

Borger, R., Babylonisch-Assyrische Lesestücke, wyd. 3 (Analecta Orientalia 54; Roma: Pontificio Istituto Biblico 2006) I-II.

Borger, R. et al. (red.), Texte aus der Umwelt des Alten Testaments, wyd. 2 (Gütersloh: Mohn 2004) I-III (=TUAT AF).

Bottéro, J. - Petschow, H., „Homosexualität”, Reallexikon der Assyriologie (red. E. Ebeling et al.) (Berlin: De Gruyter 1972-1975) 459-468.

Drewnowska-Rymarz, O. et al. (tł.), Mity akadyjskie (Antologia Literatury Mezopotamskiej; Warszawa: Agade 2000).

Black, J.A. et al., The Electronic Text Corpus of Sumerian Literature, http://etcsl.orinst.ox.ac.uk/ [dostęp: 4.12.2020] (=ETCSL).

Foster, B.R., Before the Muses. An Anthology of Akkadian Literature, wyd. 3 (Bethesda, MD: CDL Press 2005) I-II. 
Freedman, D.N. (red.), Anchor Bible Dictionary (New York: Doubleday 1992) I-VI (=ABD).

Gagnon, R.A.J., The Bible and Homosexual Practice. Texts and Hermeneutics (Nashville, TN: Abingdon Press 2010).

Gadd, C.J., Cuneiform Texts from Babylonian Tablets in the British Museum (London: British Museum 1926) XXXIX (=CT 39).

George, A.R., The Babylonian Gilgamesh Epic. Introduction, Critical Edition and Cuneiform Texts (Oxford: Oxford University Press 2003) I-II.

Gibson, J.C.L. - Driver, G.R., Canaanite Myths and Legends (Edinburgh: Clark 1978).

Gordon, E.I., The Sumerian Proverbs. Glimpses in Everyday Life in Ancient Mesopotamia (Philadelphia, PA: University of Pennsylvania Press 1959).

Grayson, A.K. - Redford, D.B., Papyrus and Tablet (Englewood Cliffs, NJ: Prentice-Hall 1973).

Greenberg, D.F., The Construction of Homosexuality (Chicago, IL: University of Chicago Press 1988).

Guinan, A.K., „Auguries of Hegemony: The Sex Omens of Mesopotamia”, Gender \& History 9 (1997) 462-479.

Hallo, W.W., The Context of Scripture (red. K.L. Younger Jr.) (Leiden: Brill 1997-2002) I-III. $(=\mathrm{CoS})$

Halperin, D.M., One Hundred Years of Homosexuality and Other Essays on Greek Love (New York - London: Routledge 1990).

Heimpel, W., Letters to the King of Mari. A New Translation, with Historical Introduction, Notes and Commentary (Mesopotamian Civilization 12; Winona Lake, IN: Eisenbrauns 2003).

Horner, T., Jonathan Loved David. Homosexuality in the Biblical Times (Philadelphia, PA: Westminster 1978).

Jacobsen, T., The Harps That Once... Sumerian Poetry in Translations (New Haven, CT: Yale University Press 1987).

Leick, G., Sex and Eroticism in Mesopotamian Literature (London - New York: Routledge 1994).

Lipiński, E., Prawo bliskowschodnie w starożytności. Wprowadzenie historyczne (Studia Historico-Biblica 2; Lublin: Wydawnictwo KUL 2009).

Livingstone, A., Court Poetry and Literary Miscellanea (State Archives of Assyria 3; Helsinki: Helsinki University Press 1989).

Łyczkowska, K. - Puchta, P. - Kapełuś, M. (tł.), Epos o Gilgameszu (Antologia Literatury Mezopotamskiej; Warszawa: Agade 2003).

Maul, S.M., „kurgarrû und assinnu und ihr Stand in der Babylonischer Gesellschaft”, Außenseiter und Randgruppen. Beiträge zu einer Sozialgeschichte des Alten Orients (red. V. Haas) (Konstanzer althistorische Vorträge und Forschungen 32; Konstanz: Universitätsverlag 1992) 159-171.

Miller, J.L., „Paskuwatti's Ritual: Remedy for Impotence or Antidote to Homosexuality?”, Journal of Ancient Near Eastern Religions 10 (2010) 83-89.

Moran, W.L., „New Evidence from Mari on the History of Prophecy”, Biblica 50 (1969) 15-56.

Mouton, A., Rituels, mythes et prières hittites (Paris: Cerf 2016).

Nissinen, M., „Are There Homosexuals in Mesopotamian Literature?”, Journal of the American Oriental Society 130 (2010) 73-77.

Nissinen, M., Homoeroticism in the Biblical World. A Historical Perspective (Minneapolis, MN: Fortress 1998). 


\section{MACIEJ MÜNNICH}

Oppenheim, A.L., „Divination and Celestial Observation in the Last Assyrian Empire”, Centaurus 14 (1969) 97-135.

Oppenheim, A.L., The Interpretation of Dreams in the Ancient Near East (Transactions of the American Philosophical Society 46/3; Philadelphia: American Philosophical Society 1956.

Park, G.J., „El's member in KTU 1.23”, Ugarit-Forschungen 39 (2007) 617-627.

Parpola, S. (red.), State Archives of Assyria, http://oracc.museum.upenn.edu/saao/corpus [dostęp: 4.12.2020] (=SAA).

Peled, I., „assinnu and kurgarrû Revisited”, Journal of Near Eastern Studies 73 (2014) 283-297.

Peled, I., Masculinities and Third Gender. The Origins and Nature of an Institutionalized Gender Otherness in the Ancient Near East (Alter Orient und Altes Testament 435, Münster: Ugarit-Verlag 2016).

Pritchard, J.B. (red.), The Ancient Near Eastern Texts Relating to the Old Testament, wyd. 3 (Princeton, NJ: Princeton University Press 1969) (=ANET).

Reisman, D., „Iddin-Dagan's Sacred Marriage Hymn”, Journal of Cuneiform Studies 25 (1973) 185-202.

Richardson, M.E.J., Hammurabi’s Laws. Text, Translation, and Glossary (Biblical Seminar 73, Semitic Texts and Studies 2; Sheffield: Clark 2000).

Roth, M.T. (red.), The Assyrian Dictionary of the Oriental Institute of the University of Chicago (Chicago: Oriental Institute of the University of Chicago 1956-2006) (=CAD).

Roth, M.T., Law Collections from Mesopotamia and Asia Minor, wyd. 2 (Writings from the Ancient World Series 6; Atlanta, GA: Scholars Press 1997).

Schwemer, D. (red.), Hethitologie Portal Mainz, https://www.hethport.uni-wuerzburg.de/ HPM/ [dostęp: 4.12.2020] (=HPM).

Szarzyńska, K., Eposy sumeryjskie (Antologia Literatury Mezopotamskiej; Warszawa: Agade 2003).

Szarzyńska, K. et al., Miłość i seks w kulturach Wschodu starożytnego (Warszawa: Agade 1996).

Taylor, K., The Erra Song. A Religious, Literary, and Comparative Analysis (Dys. Harvard University; Cambridge, MA 2017).

Teppo, S., „Sacred Marriage and the Devotees of Ištar”, Sacred Marriages. The Divine-Human Sexual Metaphor from Sumer to Early Christianity (red. M. Nissinen - R. Uro) (Winona Lake, IN: Eisenbrauns 2008) 75-92.

Tinney, S. (red.), The Electronic Pennsylvania Sumerian Dictionary, http://oracc.museum .upenn.edu/epsd2 [dostęp: 1.12.2020] (=EPSD).

Tronina, A., Epos o Gilgameszu (Kraków-Mogilany: Enigma 2017).

Tyborowski, W., Prawa Hammurabiego (Poznań: Wydawnictwo Naukowe UAM 2019).

Weidner, E.F., „Aus den Tagen eines assyrischen Schattenkönigs”, Archiv für Orientforschung 10 (1935-1936) 1-48.

Winter, U., Frau und Göttin. Exegetische und ikonographische Studien zum weiblichen Gottesbild im Alten Israel und in dessen Umwelt (Orbis Biblicus et Orientalis 53; Freiburg: Universitätsverlag - Göttingen: Vandenhoeck \& Ruprecht 1983).

Wold, D.J., Out of Order. Homosexuality in the Bible and the Ancient Near East (Grand Rapids, MI: Baker 1998). 